\title{
Protecting Nature and Displacing People
}

\author{
Peter Vandergeest
}

\begin{abstract}
We usually think that national parks, wildlife sanctuaries, and other areas reserved for the protection of nature are good things but the displacement effects of protected areas have made them highly controversial in many parts of the world. However, many environmental groups see an expanded protected areas system as central to the preservation of both biodiversity and the "charismatic megafauna" which are the basis of their funding drives. Based on a discussion of the historical roots of protected areas, the globalization of nature protection and local people in conservation, this article offers alternatives to the displacement of rural populations in the name of nature conservation.
\end{abstract}

\section{Précis}

On se représente généralement les parcs naturels, les sanctuaires de vie sauvage et autres zones orientées vers la protection de la nature comme étant une bonne chose. Il s'avère cependant que l'impact sur le déplacement des populations du à ce type de zones protégées a fait de ces dernières des objets de virulentes controverses dans plusieurs régions $d u$ monde. Mais malgré tout, de nombreux groupes environnementaux considerent qu'un système élargi de zones protégées est crucial pour la préservation de la biodiversité et de la "mégafaune charismatique", qui sont les deux motifs majeurs de leur financement. En s'appuyant sur une discussion des fondements historiques de la mise en place des zones protégées, et de la mise en commun des priorités de protection de la

Peter Vandergeest is Assistant Professor of Sociology, Department of Sociology, York University, Toronto.

Paul Moore helped to gather information for this paper, and Luin Goldring provided critical comments on a earlier draft. The opinions expressed are all the responsibility of the author. nature et de préservation des populations locales, le présent article suggère des solutions alternatives au déplacement des populations rurales au nom de la Conservation de la Nature.

\section{Protected Areas and Population Displacement}

We usually think that national parks, wildlife sanctuaries, and other areas reserved for the protection of nature are good things. Many environmental groups see an expanded protected areas system as central to the preservation of both biodiversity and the "charismatic megafauna" which are the basis of their funding drives. Many people living in North American countries do not realize that the displacement effects of protected areas have made them highly controversial in many parts of the world. ${ }^{1}$

The international conservation movement, led by the World Conservation Union (IUCN), has put the expansion and proper management of a global protected areas system at the core of its activities. Although estimates of the total area classified as protected varies depend on what counts as truly protected, IUCN publications show that somewhere between 6 and 10 percent of the world's terrestrial surface is now protected (McNeely et al. 1994; World Conservation Monitoring Center 1997) and that there are about 10,000 major protected areas, up from 2000 such areas twenty years ago (Pretty and Pimbert 1995, 5). The area classified as protected continues to increase rapidly today. For example, the Thai government increased the area demarcated as national parks and wildlife sanctuaries from about 9 percent of national territory in 1986 to 18 percent in 1996 and has set a long -term goal of 25 percent of the terrestrial surface of the country (Vandergeest 1996, 261). The government of Laos has recently gazetted 18 Biodiversity Con- servation Areas covering about 10 percent of the country, following the recommendations of the IUCN (MCNeely et al. 1994, Addendum; World Conservation Monitoring Centre 1997; Intavong 1996).

This approach to conservation is based on the idea that "nature" is an object outside of humanity, an idea of nature which is widely considered to be an invention of Europeans and Americans (Evernden 1992; Guha 1989). This is true of both the scientific, mechanical vision which provides the conceptual basis for the state agencies which manage many protected areas and of the romantic vision of nature which underlies the North American preservationist movement (Guha 1989; Vandergeest and Dupius 1996). The model for managing protected areas disseminated by international conservation organizations, particularly the IUCN, has faithfully reflected this assumption until quite recently. Thus most countries adopted laws and policies for managing protected areas which either dramatically circumscribed or banned livelihood activities inside protected areas (Pretty and Pimbert 1995).

Many of the countries with high proportions of their territory classified as protected are relatively poor and contain large rural populations dependent on natural resources for their livelihoods. Estimates given by the World Conservation Monitoring Centre (1997) show the following figures (which under-report protected areas in Thailand and perhaps other countries as well): Belize (14\% of national territory), Botswana (19\%), Cambodia (17\%), Dominican Republic (22\%\%), Ecuador (24\%), Malawi (11\%), $\mathrm{Na}$ mibia (12\%), Panama (17\%), Rwanda (12\%), Senegal (11\%), Sri Lanka (12\%), and Tanzania (15\%) (World Conservation Monitoring Centre 1997). Although population densities may be 
low, these areas are typically inhabited and used by rural people. Thus the classification of large areas inevitably produces widespread displacement of local populations. The result has been a series of controversies and violent conflicts which belie the benign and pacific image of third world wilderness protection often portrayed in nature shows and fundraising drives in North America.

\section{The Historical Roots of Protected Areas}

Although the standard account of the history of protected areas usually traces it directly to Yellowstone and the American National Park ideal, this approach to nature conservation has a more complex history than just the progressive spread of the American wilderness ideal. First, the notion of the park and the emphasis on wildlife preservation among some environmental groups can be traced to hunting preserves created by aristocratic classes in Europe and, to a lesser extent, South Asia (Gadgil and Guha $1993,86,107-8$ ). Although we usually think about the English enclosure movement as the displacement of peasants to make room for sheep, this same movement also enclosed spaces reserved for sport hunting for male aristocrats, eliminating popular access to these forests. Anyone who has watched some of the recent movies based on Jane Austen's books might have noticed that sport hunting remained important for elite English men into the 19th century.

As England became a colonial power, colonial officials used sport hunting to demonstrate English manhood and racial superiority and subsistence hunting to facilitate imperial expansion through the provision of food for their expeditions (MacKenzie 1988; Neumann 1995). Colonization was accompanied by the massive slaughter of wildlife especially in Africa, but colonial hunters blamed the resulting decline of wildlife populations on livelihood hunting by local populations. Their solution was regulations banning hunting methods other than those they considered sporting and the demarcation of game reserves where strict regulations limited popular access. This solution thus drew on the history and culture of the enclosures in England, transferring the idea of the British elite private park to Africa (Neumann 1995). In many parts of colonial Africa, local people were displaced or forced to resettle to make way for game reserves. Although a second generation of wildlife enthusiasts later moved away from sport hunting to sport photography, their legacy for the international conservation movement was one of intolerance for local use of protected areas and for the methods of practical hunting such as traps and snares.

The second history contributing to the protected areas approach has been that of the American-Canadian national park. The world's first and most famous national parks, including Yellowstone in the United States and Banff in Canada, were intended to preserve areas of wilderness in the face of the disappearing American frontier. They were chosen to preserve natural areas whose grandeur and timelessness could be linked to the grandeur of the nation.

Unlike the game reserve movement, the national park movement in North America was based on the elimination of all human activities except observation. In the case of Yellowstone, for example, native inhabitants were either moved to reservations or were driven out by the army (Pretty and Pimbert 1995,5). The romantic, ascetic, and Calvinist John Muir was even more convinced about the need to separate human use from wilderness areas than were the milder technocrats associated with conservationist Gifford Pinchot. The preservationist vision identified with John Muir and American National Parks continues to inform most efforts to expand protected areas around the world (Guha 1989). This vision was made possible by the Euro-American image of wild America as either free of people altogether or inhabited only by "wild" people who could be domesticated by relocation into permanent farming communities.

Like the colonial game reserves, then, national parks were tied to policies displacing local populations to make way for nature and wilderness. In the case of national parks, however, the object was to make these areas available for viewing by middle-class urban citizens. The more popular basis of national parks made this designation a more useful one than game reserves for mobilizing urban support for the expansion of protected areas. The model was thus quickly adopted by the colonial wildlife preservation movement, and, in areas where tourism was important, game reserves were made into national parks (MacKenzie 1988, 262-92).

A third important strand which contributed to the modern protected areas model were state policies claiming valuable resources for the state and the model of scientific forestry adopted by colonial and post-colonial forest departments. Forests provided valuable resources in the form of timber, firewood, and non-timber forest products for colonial governments. Colonial governments claimed valuable forests as state property by gazetting them as reserve forests and placing them under the jurisdiction of state forestry departments. Most reserve forests were created not to protect wilderness, but to maximize the production of timber and other valuable resources by the application of scientific forestry. In many of these forests local populations practiced a swidden agriculture, also labelled "slash and burn" by its detractors. Swidden practices included cutting and controlled burning to create temporary farming plots in the forest, practices which were incompatible with scientific management for timber and firewood. As a result, forestry officials were usually extremely intolerant of local livelihood activities. These same forestry officials were often among the most enthusiastic hunters, which reinforced their disdain for rural people.

Colonial officials trained members of the colonized elite as foresters. 
These foresters took over forestry departments after decolonization and maintained the basic approach and attitudes of their former bosses. In many countries, protected areas have been created out of reserve forests and placed under the jurisdiction of forestry departments. Many of the officials who today manage these national parks, wildlife sanctuaries, and other protected areas categories are thus trained as foresters and consider local people as a threat to the integrity of the forest. This is in turn linked to the way that many state agencies continue to see the creation of protected areas both as a way of claiming valuable resources, such as income from international tourism (Peluso 1993), and as a way of obtaining international support for extending their control over territory and rural populations (Vandergeest 1996).

\section{The Globalization of Nature Protection}

Although it is possible to trace other influences on the modern protected areas model, these three should suggest why an approach which marginalizes or excludes local populations has become deeply ingrained. The approach has been written into the laws and policies governing protected areas around the world. The first such legal model was the 1933 Convention for the Protection of Flora and Fauna of Africa, also called the London Convention. This convention created standard definitions for national parks, a model for creating categories of protected wildlife species and guidelines for hunting restrictions (MacKenzie 1988, 217).

Although specific definitions have since been revised, the basic approach set up by this Convention has been the basis for protected areas laws and policies throughout the world. The approach has obtained the support of many environmentalists and ecologists for whom human activities such as hunting, trapping, cutting, burning, and agriculture are incompatible with biodiversity and protecting wildlife. More than this, governments looking for ways to simplify their administration of rural populations and gain access to funding and resources are now among the strongest supporters of this approach. In other words, preservationism is no longer just American, as Guha (1989) argued, but has become global, with support among diverse groups, and written into the laws, institutions, and practices which comprise protected areas around the world.

\section{Local People in Conservation}

Many environmentalists working in the third world have now launched a critique of this approach, arguing that local people, far from being destroyers of nature, are conservers of nature (Guha 1989; Watershed). These critics point out that livelihood activities can often increase biodiversity by increasing ecosystem diversity and that most so-called natural areas have been transformed or managed by local people for a long time. For example, clearings made in forests for swidden agriculture are important for large mammals, and protected areas managers in tropical countries who succeed in preventing these activities often have to create these clearings themselves. Critics of the model also argue that local people dependent on forests and local ecosystems for their survival have strong incentives for protecting these ecosystems. The conclusion is that local people should be included in the planning and management of protected areas and should certainly not be displaced from these areas.

The combination of this critique and the seemingly unresolvable conflicts which always seem to accompany the creation of protected areas has induced many international conservation organizations to endorse new approaches to protected areas planning. Some key features of this new approach are: first, that protected areas should be made economically attractive to local people by, for example, replacing lost livelihoods by including local people in the benefits obtained from protected areas; second, that the declaration of protected areas should be accompanied by rural development projects which allow for limited use of resources in buffer zones and other demarcated areas; and third, that protected areas planning should include participation by local people. Organizations like the World Wide Fund for Nature (formerly World Wild Fund, WWF) now have number of projects in which they are trying to implement this approach, while the IUCN, the World Bank, the United Nations Development Programme (UNDP), and other major international organizations want to see words like local participation in proposals drawing on funds like the Global Environmental Facility (GEF). Conservationists are now also looking for successful examples of protected areas which do not exclude local people.

It remains to be seen whether the major international conservation organizations can in fact change an approach which is so deeply ingrained in the history, the laws, culture, and practices of many thousands of protected areas. While organizations like the WWF have many projects trying out ways of involving local people, these projects represent only a very small fraction of the thousands of protected areas around the world. In the vast majority of protected areas, the old approach prevails, and many conservationists and environmental organizations are not convinced by the new approach. More than this, major recent additions to the global protected areas system are in practice based on the old model, despite the rhetorical attention given to words like participation. For example, the recent gazetting of an enormous area of Laos as Biodiversity Conservation Areas took place with very little input from rural people. These areas are part of Lao government policies which aim to stop deforestation-which official state policy blames on swidden agriculture-by resettling upland rural people into lowland villages where they are supposed to practice modern, permanent farming. In Thailand, a recent proposal for major GEF funding includes substantial funding for military 
equipment (guns, helicopters) to be used for guarding protected areas (Vandergeest 1996, 265). This highlights what I believe will be a major obstacle to the implementation of a new approach: the commitment of many state agencies in poor countries to the old, exclusionary approach to protected areas as a way of gaining access to international funding to facilitate better control over territory and rural people.

Where projects have included participation, the terms under which this participation takes place is often defined by the basic protected areas model. Thus many IUCN staff now argue for allowing livelihood uses in protected areas, but only if they are "traditional." Since the definition of traditional is often very narrow, many existing uses are not included, and the definition of what should be allowed is often determined by states or international conservation groups rather than through discussions with local users. My experience in Thailand shows that even local environmentalists who argue for turning over the management of protected areas to local people are often ready to endorse laws limiting livelihood uses to those defined as traditional, partly because they believe that rural people embody a critique of modernity.

Another approach would be to rethink the current emphasis on the expansion of protected areas rather than just rethinking how protected areas are to be managed. Protected areas create islands of nature, while environmental degradation outside of these areas proceeds apace. This degradation is driven by high consumption by the same urban middle and elite classes who support the expansion of national parks and wildlife sanctuaries in the name of wilderness protection. In the long run, protected areas cannot be isolated from global environmental changes anyway. Some ecologists are predicting widespread destruction of forests if or when global warming begins to set in. In other words, the islands of nature approach might be self-defeating in the long run. Moving away from the protected areas approach would help move the international conservation agenda to a more broad based approach to ecosystem maintenance, one not limited spatially by protected areas. This would have the added benefit of avoiding the injustices produced by the displacement of rural populations in the name of nature conservation.

\section{Notes}

1. Sample readings on the displacement effects of protected areas include West and Brechin's (1991) edited volume; Pretty and Pimbert's (1995) overview; Laungaramsri and Rajesh (1996) and Vandergeest (1996) on Thailand; Stycos and Duarte on the Dominican Republic; Neumann (1995), Peluso (1993), and McCabe et al. (1992) on Africa.

\section{References}

Evernden, Neil. 1992. The Social Creation of Nature. Baltimore: The Johns Hopkins University Press.

Fitter, Richard, and Sir Peter Scott. 1978. The Penitent Butchers. London: Fauna Preservation Society.

Gadgil, Madhav, and Ramachandra Guha. 1993. This Fissured Land: An Ecological History of India. Delhi: Oxford University Press.

Guha, Ramachandra. 1989. "Radical American Environmentalism and Wilderness Preservation: A Third World Critique." Environmental Ethics 11, 71-83.

Intavong, Chanataviphone. 1996. Cited in Laungaramsri, Pinkaew, and Noel Rajesh, "Redefining Conservation: A Critique of Protected Areas in Thailand." Watershed 1, no. 2, 27.

Laungaramsri, Pinkaew, and Noel Rajesh. 1996. "Redefining Conservation: A Cri- tique of Protected Areas in Thailand." Watershed 1, no. 2, 14-28.

MacKenzie, John M. 1988. The Empire of $\mathrm{Na}$ ture: Hunting, Conservation and British Imperialism. Manchester: Manchester University Press.

McCabe, J. Terrence, Scott Perkin, and Claire Schofield. 1992. "Can Conservation and Development be Coupled Among Pastoral People?" Human Organization 51, no. 4.

McNeely, Jeffery A., J. Harrison, and P. Dingwall, eds. 1994. Protecting Nature: Regional Reviews of Protected Areas. IUCN.

Neumann, Roderick. 1995. "Ways of Seeing Africa." Ecumene 2, no. 2, 149-69.

Peluso, Nancy Lee. 1993. Coercing Conservation: The Politics of State Resource Control. Global Environmental Change (June): 199-218.

Pretty, Jules N., and Michel P. Pimbert. 1995. "Beyond Conservation Ideology and the Wilderness Myth." Natural Resources Forum 19, no. 1, 5-14.

Stycos, J. Mayone, and Isis Duarte. 1995. "Parks, Resettlement, and Population: A Case Study in the Dominican Republic." Society and Natural Resources 8, 243-60.

Vandergeest, Peter. 1996. "Property Rights in Protected Areas: Obstacles to Community Involvement as a Solution in Thailand." Environmental Conservation 23, no. 3, 259-68.

Vandergeest, Peter, and E. Melanie Dupuis 1996. "Introduction." In Creating the Countryside, edited by E. Melanie Dupuis and Peter Vandergeest, 1-25. Philadelphia: Temple University Press.

Watershed. 1996. Vol. 1, no. 2.

West, Patrick C., and Steven R. Brechin. 1991 Resident Peoples and National Parks. Tuscon: The University of Arizona Press.

World Conservation Monitoring Centre. 1997. "Statistics of Protected Areas Worldwide.http://www.wcmc.org.uk/ protected_areas/data/summstat.html $\square$

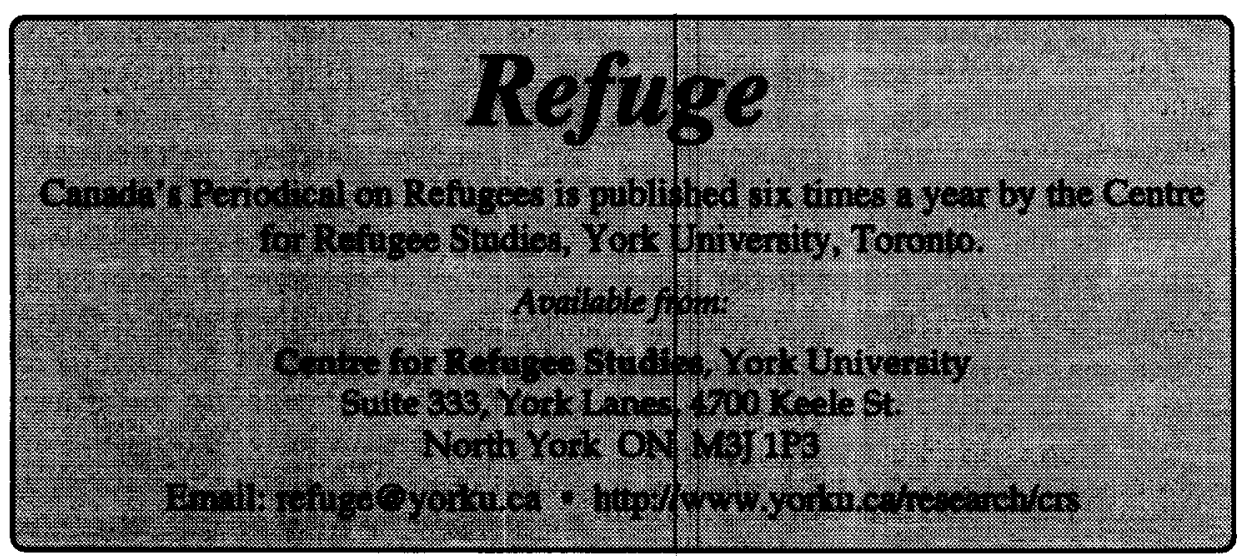

